\title{
Effect of liquid property on adsorption and catalytic reduction of nitrate over hydrotalcite-supported $\mathrm{Pd}-\mathrm{Cu}$ catalyst
}

\author{
Ying Wang ${ }^{\text {a,b }}$, Jiuhui Qu ${ }^{\text {a,* }}$, Huijuan Liu ${ }^{\text {a }}$ \\ a State Key Laboratory of Environmental Aquatic Chemistry, Research Center for Eco-Environmental Sciences, Chinese Academy of Sciences, \\ 18 Shuangqing Road, Haidian District, Beijing 100085, China \\ ${ }^{\mathrm{b}}$ State Key Laboratory of Water Environment Simulation, School of Environment, Beijing Normal University, Beijing 100875, China
}

Received 10 January 2007; received in revised form 17 February 2007; accepted 19 February 2007

Available online 23 February 2007

\begin{abstract}
This study focused on investigating the effect of liquid property on adsorption and catalytic reduction of nitrate over hydrotalcite-supported $\mathrm{Pd}-\mathrm{Cu}$ catalyst. Batch experiments were conducted under specific operating conditions. It was found that nitrate ions were adsorbed apparently by hydrotalcite-supported Pd-Cu catalyst at different reaction temperature $\left(10,25\right.$ and $\left.35^{\circ} \mathrm{C}\right)$. Adsorption isotherms for $\mathrm{NO}_{3}{ }^{-}$were described by Langmuir's equation. Higher reaction temperature accelerated nitrate adsorption and reduction, and simultaneously decreased the accumulation of $\mathrm{NO}_{2}{ }^{-}$and $\mathrm{NH}_{4}{ }^{+}$. Nitrate adsorption and reduction were independent of the initial $\mathrm{pH}$ because of the high buffering capacity of hydrotalcite when the initial $\mathrm{pH}$ of solution was from 5.25 to 7.4. However, the dissolve of hydrotalcite-supported Pd-Cu catalyst at low initial pH (3.77) and higher concentration of $\mathrm{OH}^{-}$ions at high initial $\mathrm{pH}(10.74)$ decreased nitrate adsorption and reduction. When using various nitrate salts as a source of nitrate ions, nitrate adsorption and reduction removal efficiency decreased in the order: $\mathrm{Fe}^{3+}>\mathrm{Mn}^{2+}>\mathrm{Mg}^{2+}>\mathrm{Ca}^{2+}>\mathrm{Na}^{+}$, which was attributed to different affinity toward $\mathrm{OH}^{-}$. Co-existed cations in water with higher valence and lower crystal ionic radius and solubility constant of hydroxide showed stronger affinity toward $\mathrm{OH}^{-}$and consequently increased the concentration of active sites accessible to $\mathrm{NO}_{3}{ }^{-}$and $\mathrm{NO}_{2}{ }^{-}$. The competitive adsorption of $\mathrm{Cl}^{-}, \mathrm{SO}_{4}{ }^{2-}$ and $\mathrm{HCO}_{3}{ }^{-}$with nitrate on the catalyst surface suppressed the adsorption and reduction of $\mathrm{NO}_{3}{ }^{-}$. Besides, few metals dissolved in neutral and alkaline solution. The activity of the hydrotalcite-supported Pd-Cu catalyst for nitrate reduction kept steady after repeated use.
\end{abstract}

(C) 2007 Elsevier B.V. All rights reserved.

Keywords: Liquid property; Pd-Cu/hydrotalcite; Catalytic; Adsorption; Nitrate reduction

\section{Introduction}

The nitrate ions removal from groundwater is becoming an environmental problem of major concern due to its high toxicity (e.g. causing cancer and nethemoglobinemia) $[1,2]$. Conventional physicochemical methods, including ionexchange, reverse osmosis and electrodialysis [3,4], allow effective removal of nitrate ions from water by concentrating them in a secondary waste stream, but do not generally achieve their complete disposal. The most environmental friendly methods for nitrate removal, based on selective reduction of nitrate to nitrogen, are biological digestion $[5,6]$ and catalytic reduction $[7,8]$. The biological denitrification process is currently the most widely used, however, possible bacterial contamination,

\footnotetext{
* Corresponding author. Tel.: +86 1062849151 ; fax: +86 1062923558.

E-mail address: jhqu@mail.rcees.ac.cn (J.H. Qu).
}

the presence of residual organics and the possible increase in chlorine demand in purified water [3] limit the application of this process.

The catalytic reduction of nitrate is attracting considerable interest due to many advantages, such as efficient chemical reaction, flexibility, simple configuration of reactor, etc. In this process, nitrate ions are reduced using hydrogen over bimetallic catalyst. The reaction obeys a consecutive reaction scheme in which nitrite appears as an intermediate, while nitrogen and ammonia are the final products. Recently, developing a catalyst possessed higher activity and selectivity for nitrate reduction [9-11] and studying the influence of liquid properties [12-14], such as temperature, $\mathrm{pH}$, co-existed ions, etc., have received many researchers' attention.

In our previous study [15], hydrotalcite (HT)-supported $\mathrm{Pd}-\mathrm{Cu}$ catalysts for nitrate reduction using hydrogen were investigated preliminarily. Hydrotalcite like compounds, as one of the most promising materials, were widely used as catalyst [16], 
catalyst support [17], adsorbent [18], etc. The general chemical formula is written as $\left[\mathrm{M}^{\mathrm{II}}{ }_{1-x} \mathrm{M}^{\mathrm{III}}{ }_{x}(\mathrm{OH})_{2}\right]^{x+}\left[\mathrm{A}^{n-}{ }_{x / n}\right]^{x-} \cdot y \mathrm{H}_{2} \mathrm{O}$, where $\mathrm{M}^{\mathrm{II}}$ and $\mathrm{M}^{\mathrm{III}}$ are divalent and trivalent metal ions, $\mathrm{A}^{n-}$ is a $n$-valent anion and $x$ can have values approximately between 0.25 and 0.33 . This material presents a brucite-like structure, where metallic cations are located in the layer, while anions and water are found in the interlayer space. Therefore, $\mathrm{Pd}-\mathrm{Cu}$ active metals could be introduced into the layers to obtain high dispersion, which may increase the stability and activity of the catalyst; toxic anions (such as nitrate) in contaminated water may be concentrated in the interlayer space to be removed.

Our preliminary experiments have shown that hydrotalcitesupported $\mathrm{Pd}-\mathrm{Cu}$ catalyst possessed effective adsorptive and catalytic capacity for nitrate in water [15]. The reaction scheme for nitrate removal on $\mathrm{HT} 3(\mathrm{Pd}-\mathrm{Cu})$ catalyst, with $\mathrm{H}_{2}$ provided, was a consecutive and dynamic adsorption and catalytic hydrogenation process. Then, it is a key to investigate the influence of liquid property, including temperature, $\mathrm{pH}$ and co-existed ions in water, on nitrate adsorption and reduction over hydrotalcite-supported $\mathrm{Pd}-\mathrm{Cu}$ catalyst, which will be favorable for the determining the appropriate reaction conditions for nitrate reduction. From this aspect, systematical experiment was necessary to conducted in this paper.

\section{Experimental}

\subsection{Catalyst preparation}

Hydrotalcite-supported Pd-Cu catalyst was prepared by coprecipitation at low supersaturation method [19]. In this method, two solutions, A and B, were added dropwise into a beaker containing $100 \mathrm{~mL}$ of deionic water while vigorous stirring. Solution A was $\mathrm{Mg}\left(\mathrm{NO}_{3}\right)_{2}(1.2 \mathrm{~mol} / \mathrm{L}), \mathrm{Al}\left(\mathrm{NO}_{3}\right)_{2}(0.4 \mathrm{~mol} / \mathrm{L})$, an appropriate amount of $\mathrm{Pd}\left(\mathrm{NO}_{3}\right)_{2} \cdot 2 \mathrm{H}_{2} \mathrm{O}$ and $\mathrm{Cu}\left(\mathrm{NO}_{3}\right)_{2} \cdot 3 \mathrm{H}_{2} \mathrm{O}$ mixed aqueous solution. The palladium and copper content are 1 and 0.25 wt. $\%$, respectively. Solution B contained $1.65 \mathrm{~mol} / \mathrm{L} \mathrm{NaOH}$ and $0.5 \mathrm{~mol} / \mathrm{L} \mathrm{Na} \mathrm{CO}_{3}$. During the process of synthesis, the $\mathrm{pH}$ of the suspensions was maintained at about 10 . The resulting suspension was then maintained at $25^{\circ} \mathrm{C}$, with stirring, for $4 \mathrm{~h}$. The product was filtered, washed thoroughly with deionised water until the $\mathrm{pH}$ of filtrate showed neutral and subsequently dried overnight at $105^{\circ} \mathrm{C}$ and calcined at $550^{\circ} \mathrm{C}$ for $8 \mathrm{~h}$, finally reduced at $200{ }^{\circ} \mathrm{C}$ for $2 \mathrm{hr}$ under flowing hydrogen/argon. The final product was mentioned as $\mathrm{HT} 3(\mathrm{Pd} / \mathrm{Cu})$.

\subsection{Catalyst characterization}

The specific surface area (BET method) was determined using an ASAP2000 Surface Analyser (Micromeritics Co., USA) using $\mathrm{N}_{2}$ as the adsorbate.

$\mathrm{X}$-ray powder diffraction (XRD) patterns of samples were obtained with a Bruker diffractometer using $\mathrm{Cu} \mathrm{K} \alpha$ radiation from $10^{\circ}$ to $70^{\circ}$ (in $2 \Theta$ ).

Fourier transform infrared spectra were recorded with potassium bromide-pressed disks, by accumulating 32 scans at $4 \mathrm{~cm}^{-1}$ resolution between 400 and $4000 \mathrm{~cm}^{-1}$ using a Nicolet 5700 Fourier transform infrared spectrometer (FTIR).
Thermogravimetry (TG) and differential thermal analysis (DTA) of the sample was carried out using a Labsys ${ }^{\mathrm{TM}}$ TG-DSC Simultaneous Analyser referenced against recalcined alumina (SETRAM Co.), in flowing nitrogen (flow rate, $20 \mathrm{~mL} / \mathrm{min}$ ), at a heating rate of $10^{\circ} \mathrm{C} / \mathrm{min}$.

\subsection{Adsorptive and catalytic tests}

For all adsorptive tests in this work, the studies were carried out in glass vessels with agitation provided by a shaker at $170 \mathrm{rpm}$ and the temperature controlled by air bath. Nitrate solution $(50 \mathrm{~mL})$ was mixed with $0.1 \mathrm{~g}$ catalyst. Samples were taken at different time intervals. The initial nitrate concentration was equal to $100 \mathrm{mg} / \mathrm{L}$. The adsorption equilibrium was obtained within $180 \mathrm{~min}$, which was demonstrated in our previous study [15]. Consequently, the adsorption time was $180 \mathrm{~min}$.

Catalytic capacity of different catalyst for nitrate reduction was tested in a thermostated batch reactor equipped with $\mathrm{H}_{2}$ inlet and outlet and a sample port. The catalyst ( $1 \mathrm{~g})$ was suspended in pure water $(500 \mathrm{~mL})$, which was saturated with the mixture of $\operatorname{argon}(400 \mathrm{~mL} / \mathrm{min})$ and hydrogen $(200 \mathrm{~mL} / \mathrm{min})$ from the titanium plate situated in the bottom of the reactor for $60 \mathrm{~min}$. Solution containing nitrate was introduced and the time was started. The initial nitrate concentration was equal to $100 \mathrm{mg} / \mathrm{L}$. The reaction time was $180 \mathrm{~min}$.

\subsection{Analysis methods}

Samples were taken from the reactor at desired sampling times and filtered through a $0.45 \mu \mathrm{m}$ membrane. $\mathrm{NO}_{3}{ }^{-}-\mathrm{N}$, $\mathrm{NO}_{2}{ }^{-}-\mathrm{N}$ and $\mathrm{NH}_{4}{ }^{+}-\mathrm{N}$ were determined using a Hitachi-3010 model UV-spectrophotometer.

After the reaction, solution in the reactor was analyzed by ICP-AES (Perkin-Elmer Co.) to quantify any dissolving of the active metals $\left(\mathrm{Mg}^{2+}, \mathrm{Al}^{3+}, \mathrm{Pd}^{2+}, \mathrm{Cu}^{2+}\right)$.

\section{Results and discussion}

\subsection{Characterization of catalyst}

The physical properties of the catalyst were very important and influenced the catalytic capacity of the catalyst remarkably. Before the calcination, the sample had a low specific surface area of $6.2 \mathrm{~m}^{2} / \mathrm{g}$. The X-ray diffraction (XRD) analysis showed that a well-crystallized hydrotalcite-like phase formed. After calcination, the specific surface area increased to $236.6 \mathrm{~m}^{2} / \mathrm{g}$. Meanwhile, hydrotalcite-like structure was changed while $\mathrm{MgO}$ phase was formed according to the peaks at $43.2^{\circ}$ and $62.7^{\circ}$. After the sample contacted with the aqueous solution of nitrate, the specific surface area dropped to the value as low as $9.05 \mathrm{~m}^{2} / \mathrm{g}$. Simultaneously, $\mathrm{MgO}$ phase collapsed and turned into a hydrotalcite-like phase which was evidenced by the XRD analysis. This result sample was just the active catalyst during the denitrification process. In addition, due to the low active metals content, no peak related with $\mathrm{Pd}-\mathrm{Cu}$ could be observed.

In order to clarify the decomposition process during the calcination, simultaneous thermogravimetry (TG) and differential 


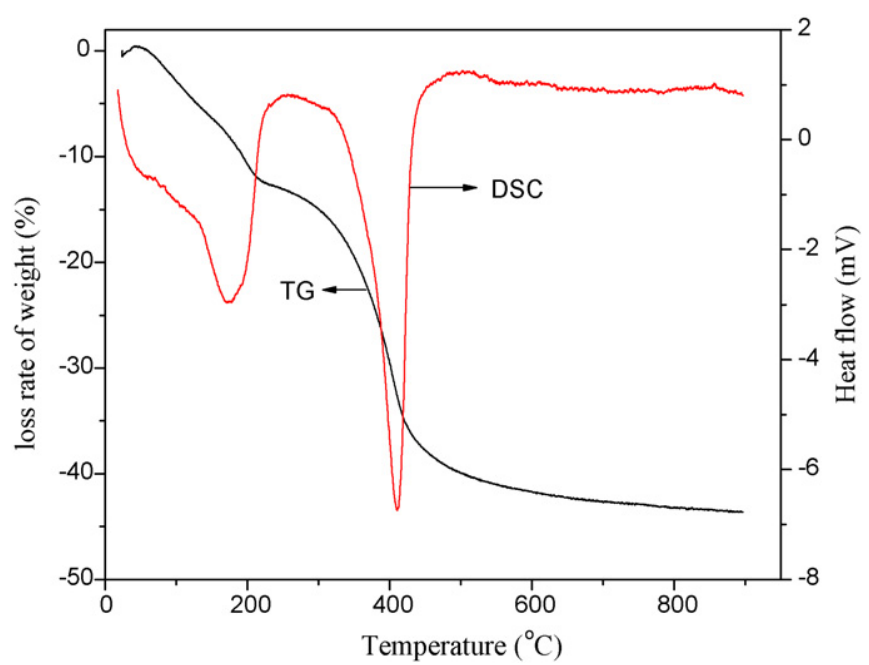

Fig. 1. Simultaneous TG/DSC thermogram of the HT3(Pd-Cu).

thermal analysis techniques were carried out. The result was shown in Fig. 1. As TG analysis revealed, gradual weight loss was observed from about $50^{\circ} \mathrm{C}$ to approximately $600^{\circ} \mathrm{C}$, with two main endothermic effects at about 173 and $410^{\circ} \mathrm{C}$. The first large endothermic effect at about $173^{\circ} \mathrm{C}$ involved interlayer water loss [20]; the second endothermic effect at $410^{\circ} \mathrm{C}$ accounted for hydrotalcite decomposition which was accompanied by dehydroxylation and the decomposition of $\mathrm{CO}_{3}{ }^{2-}$ in the brucite-like layers [20]. Carbon dioxide evolution induced the formation of pores, which was the reason for the drastic increase in the specific surface area. The total weight loss ( $c a .40 \%$ of the starting mass) is similar to that calculated from weights taken before and after calcination.

\subsection{Effect of liquid property on adsorption and catalytic reduction of nitrate on $\mathrm{HT} 3(\mathrm{Pd}-\mathrm{Cu})$}

For the natural water, the property of the liquid phase was obviously various in different area. Therefore, the effect of the liquid property on the adsorption and catalytic hydrogenation for nitrate over hydrotalcite-supported $\mathrm{Pd}$-Cu catalyst should be discussed in detail.

\subsubsection{The effect of temperature}

The influence of temperature on nitrate uptake and catalytic hydrogenation over $\mathrm{HT} 3(\mathrm{Pd} / \mathrm{Cu})$ was discussed, respectively. Fig. 2(a) showed adsorption isotherm for $\mathrm{NO}_{3}{ }^{-}$at temperature of 10,25 and $35^{\circ} \mathrm{C}$. The result showed that $\mathrm{HT} 3(\mathrm{Pd} / \mathrm{Cu})$ catalyst possessed apparent adsorption capacity for $\mathrm{NO}_{3}{ }^{-}$, especially at 25 and $35^{\circ} \mathrm{C}$, which could be explained by considering the capacity of hydrotalcite to concentrate anions in the interlayer space. Although the specific surface area of the regenerated hydrotalcite was very low, nitrate ions could be concentrated by ionic forces between the layers. Therefore, effective adsorption for nitrate was obtained.

Additionally, adsorption data were tested using Langmuir model. It was discovered that, at different temperature, adsorption isotherm for $\mathrm{NO}_{3}{ }^{-}$fit well with Langmuir's equation
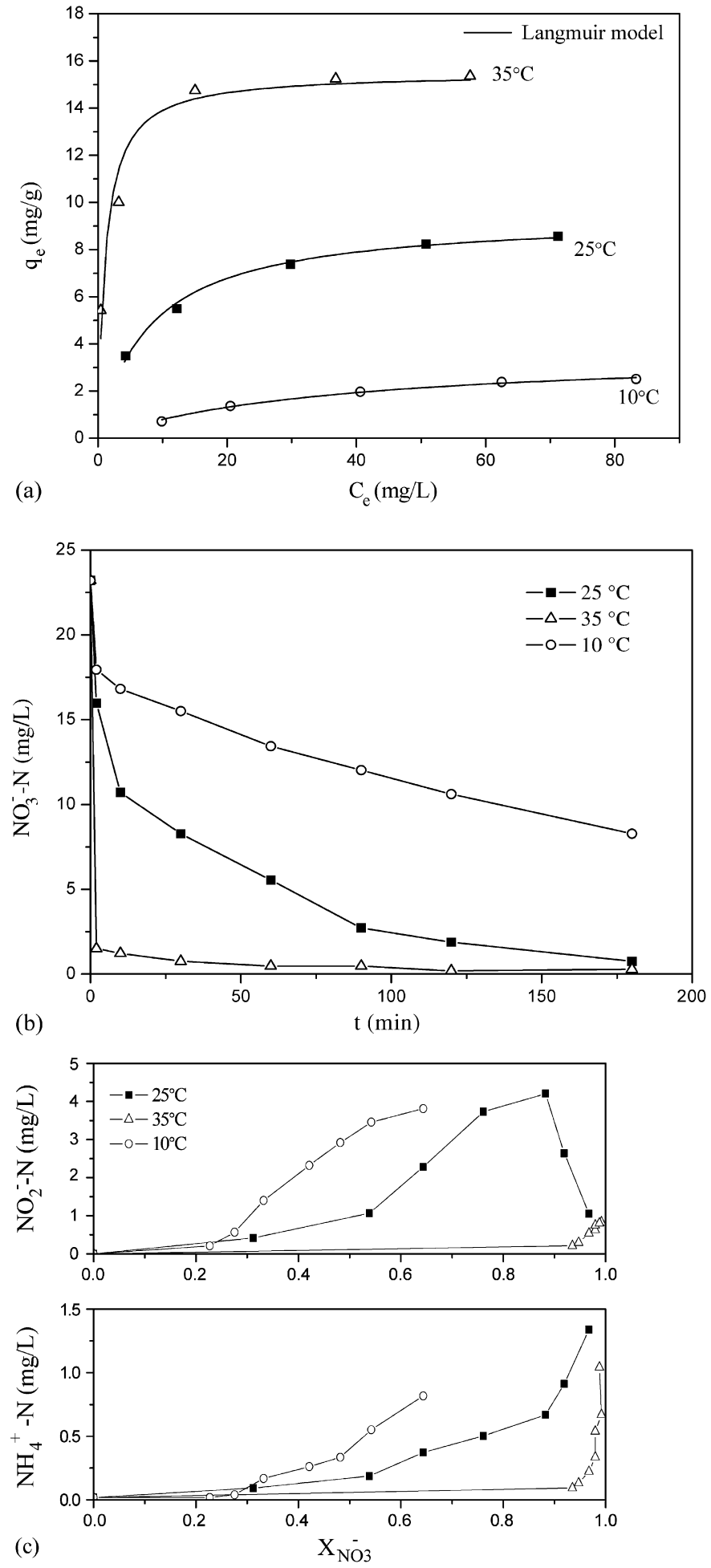

Fig. 2. The effect of temperature on the adsorption and reduction of nitrate over HT3(Pd-Cu), without pH control: (a) adsorption isotherms of $\mathrm{NO}_{3}{ }^{-}-\mathrm{N}$; (b) $\mathrm{NO}_{3}{ }^{-}-\mathrm{N}$ concentration with time during the catalytic hydrogenation of aqueous nitrate solution; (c) $\mathrm{NO}_{2}{ }^{-}$and $\mathrm{NH}_{4}{ }^{+}$concentration with $\mathrm{NO}_{3}{ }^{-}$conversion during the catalytic hydrogenation of aqueous nitrate solution $\left(\mathrm{X}_{\mathrm{NO}_{3}-}=\right.$ $\left(\left[\mathrm{NO}_{3}{ }^{-}\right]_{t=0}-\left(\left[\mathrm{NO}_{3}{ }^{-}\right]_{t}\right) /\left(\left[\mathrm{NO}_{3}{ }^{-}\right]_{t=0}\right)\right.$. 
$\left(q_{\mathrm{e}}=q_{\mathrm{m}} b c_{\mathrm{e}} /\left(1+b c_{\mathrm{e}}\right)\right)$, where $q_{\mathrm{e}}(\mathrm{mg} / \mathrm{g})$ was the amount of $\mathrm{NO}_{3}{ }^{-}{ }^{-} \mathrm{N}$ adsorbed at equilibrium, $q_{\mathrm{m}}(\mathrm{mg} / \mathrm{g})$ the maximum sorption capacity corresponding to complete monolayer coverage, $c_{\mathrm{e}}(\mathrm{mg} / \mathrm{L})$ the equilibrium solute concentration and $b$ was the equilibrium constant $(\mathrm{L} / \mathrm{mg})$. The maximum adsorption capacity $\left(q_{\mathrm{m}}\right)$ obtained by the linear regression was $3.685 \mathrm{mg}-\mathrm{NO}_{3}{ }^{-}-\mathrm{N} / \mathrm{g}$ at $10^{\circ} \mathrm{C}, 9.441 \mathrm{mg}-\mathrm{NO}_{3}{ }^{-} \mathrm{-N} / \mathrm{g}$ at $25^{\circ} \mathrm{C}$, $15.491 \mathrm{mg}-\mathrm{NO}_{3}{ }^{-}-\mathrm{N} / \mathrm{g}$ at $35^{\circ} \mathrm{C}$, respectively, which suggested that the nitrate uptake obviously increased with an increase in the adsorption temperature. Usually, the uptake decreases with temperature due to the exothermic nature of the simple physical adsorption reaction. The present result indicated that a chemical interaction involved the adsorption of nitrate on $\mathrm{HT} 3(\mathrm{Pd} / \mathrm{Cu})$.

Fig. 2(b) showed the catalytic reduction of nitrate at different temperature $\left(10,25\right.$ and $\left.35^{\circ} \mathrm{C}\right)$. It was found that nitrate concentration decreased rapidly at the initial $2 \mathrm{~min}$, especially at $35^{\circ} \mathrm{C}$ nitrate removal efficiency reaching as high as $93.5 \%$. Then, $\mathrm{NO}_{3}{ }^{-}$removal efficiency became slowly gradually. After $180 \mathrm{~min}$, the total removal efficiency for nitrate was $64.37,96.76$ and $98.78 \%$ at 10,25 and $35^{\circ} \mathrm{C}$, respectively. Thus, it was concluded that higher reaction temperature may increase nitrate removal.

Simultaneously, nitrite and ammonium ions were formed during the catalytic hydrogenation for nitrate. The results were shown in Fig. 2(c). With the decrease of the reaction temperature, the concentration of $\mathrm{NO}_{2}{ }^{-}$and $\mathrm{NH}_{4}{ }^{+}$increased, that is, the selectivity for $\mathrm{N}_{2}$ decreased. At $35^{\circ} \mathrm{C}$, the concentration of $\mathrm{NO}_{2}{ }^{-}$and $\mathrm{NH}_{4}{ }^{+}$formed at the same $\mathrm{NO}_{3}{ }^{-}$conversation were the lowest. At $25^{\circ} \mathrm{C}$, nitrite concentration increased first, going through a maximum at $88 \%$ of nitrate conversion and then decreased, which indicated that nitrite was an intermediate product of the reduction of nitrate. Ammonium increased steadily because it was a final product. At $10^{\circ} \mathrm{C}$, more $\mathrm{NO}_{3}{ }^{-}$ was reduced to $\mathrm{NH}_{4}{ }^{+}$, and an increased accumulation occurred in $\mathrm{NO}_{2}{ }^{-}$change. Consequently, the results obtained indicated that higher temperatures favor the increase of nitrate reduction efficiency and selectivity for $\mathrm{N}_{2}$.

\subsubsection{The effect of $p H$}

The effect of the initial $\mathrm{pH}$ on nitrate adsorption and reduction over HT3 $(\mathrm{Pd} / \mathrm{Cu})$ was shown in Fig. 3. Diluted $\mathrm{HNO}_{3}$ and $\mathrm{NaOH}$ solutions were used for $\mathrm{pH}$ adjustments. Buffer solutions were not used in order to avoid contamination of foreign anions. The results indicated that, in the process of nitrate adsorption, the nitrate removal remained practically constant from 5.25 to 7.4 , reaching over $47 \%$. However, a significant decline occurred when the initial $\mathrm{pH}$ was 3.77 and 10.74 . In the process of nitrate catalytic reduction, at the initial $\mathrm{pH}$ of from 5.25 to 10.74 , nitrate removal decreased slightly with the increasing of $\mathrm{pH}$. There was no obviously different in the final $\mathrm{NH}_{4}{ }^{+}$concentration. However, the final $\mathrm{NO}_{2}{ }^{-}$concentration increased with the increasing of $\mathrm{pH}$, especially for $\mathrm{pH}$ of $10.74, \mathrm{NO}_{2}{ }^{-}-\mathrm{N}$ concentration reached as high as $4.85 \mathrm{mg} / \mathrm{L}$, which was about three times higher than that at $\mathrm{pH}$ of 7.4. During the process of nitrate reduction to $\mathrm{N}_{2}$, the electroneutrality of the system was maintained by the $\mathrm{OH}^{-}$ anions produced, which was supported by the observed incre-

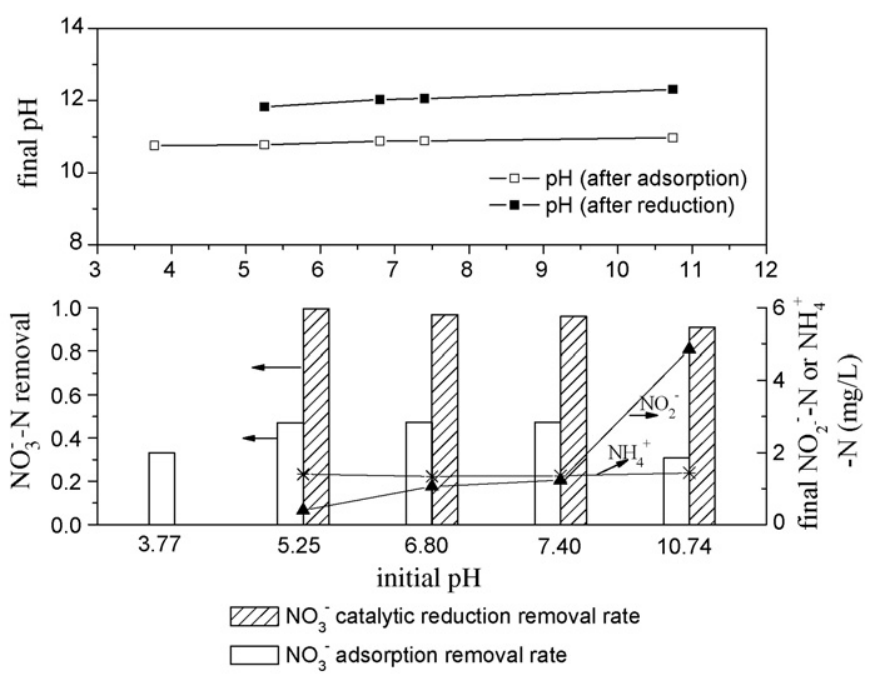

Fig. 3. The effect of the initial $\mathrm{pH}$ on the adsorption and reduction of nitrate over $\mathrm{HT} 3(\mathrm{Pd}-\mathrm{Cu}), T=25^{\circ} \mathrm{C}$.

ment of the final $\mathrm{pH}$ from adsorption process (about 10.8) to reduction process (about 12).

It was concluded that, from 5.25 to 7.4 , both nitrate adsorption and catalytic reduction processes were almost $\mathrm{pH}$ independent. Simultaneously, the relationship between the initial and equilibrium $\mathrm{pH}$ showed that, the final $\mathrm{pH}$ remained constant at about 10.8 for nitrate adsorption process and at 12 for nitrate reduction process, respectively, in spite of obvious changes of the initial $\mathrm{pH}$. These results demonstrated that hydrotalcite-like compound possessed $\mathrm{pH}$ buffering capacities at the initial $\mathrm{pH}$ of from 5.25 to 7.4, which was due to the release of hydroxyl during the regeneration of hydrotalcite structure. Therefore, at initial $\mathrm{pH}$ of from 5.25 to 7.4, nitrate adsorption (or nitrate reduction) was carried out at only one $\mathrm{pH}$ and, as a consequence, the nitrate removal remained constant irrespective to the initial $\mathrm{pH}$ of the solution due to the buffering effect of the HT3(Pd/Cu). Other authors have also observed the buffering effect of hydrotalcite-like compounds. You et al. [21] observed that the amount of $\mathrm{SeO}_{3}{ }^{2-}$ adsorption in $\mathrm{Mg}-\mathrm{Al}$ and $\mathrm{Mg}-\mathrm{Fe}$ hydrotalcites was almost constant in a wide range of $\mathrm{pH}$.

At too low initial $\mathrm{pH}$ of 3.77 , a significant decline in nitrate adsorption removal efficiency may be due to the dissolution of $\mathrm{HT} 3(\mathrm{Pd} / \mathrm{Cu})$, which was confirmed by the examination of dissolution ions by ICP-AES. At too high initial $\mathrm{pH}$ (10.74), buffering effect of $\mathrm{HT} 3(\mathrm{Pd} / \mathrm{Cu})$ disappeared. High concentration of $\mathrm{OH}^{-}$ions cause the competitive effect with $\mathrm{NO}_{3}{ }^{-}$, which decreased nitrate removal efficiency for adsorption or reduction and selectivity to $\mathrm{N}_{2}$.

\subsubsection{The effect of co-cations in water}

To study the influence of familiar anions in the aqueous solution on the adsorption and reduction of nitrate over $\mathrm{HT} 3(\mathrm{Pd} / \mathrm{Cu})$, the following reagent-grade compounds were employed as a source of nitrate ions: $\mathrm{NaNO}_{3}, \mathrm{Mg}\left(\mathrm{NO}_{3}\right)_{2}$, $\mathrm{Ca}\left(\mathrm{NO}_{3}\right)_{2}, \mathrm{Mn}\left(\mathrm{NO}_{3}\right)_{2}$ and $\mathrm{Fe}\left(\mathrm{NO}_{3}\right)_{3}$. As shown in Fig. 4, nitrate adsorption removal efficiency decreased in the order: $\mathrm{Fe}^{3+}>\mathrm{Mn}^{2+}>\mathrm{Mg}^{2+}>\mathrm{Ca}^{2+}>\mathrm{Na}^{+}$, which was on the contrary 


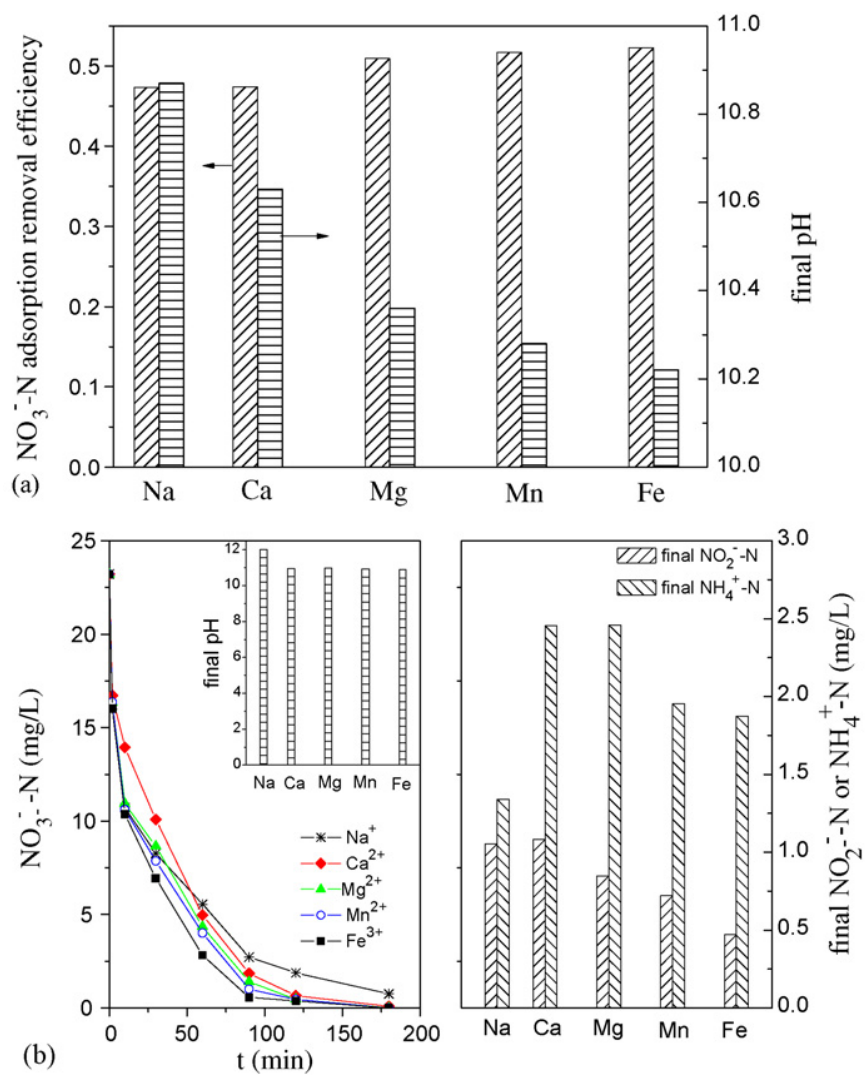

Fig. 4. The effect of the co-cations on the (a) adsorption and (b) reduction of nitrate over $\mathrm{HT} 3(\mathrm{Pd}-\mathrm{Cu}), T=25^{\circ} \mathrm{C}$, without $\mathrm{pH}$ control.

to the order of final $\mathrm{pH}$ decrease. Similarly, in the process of nitrate catalytic reduction, the order of nitrate catalytic reduction removal efficiency was consistent with the order of nitrate adsorption removal efficiency. The final $\mathrm{pH}$ in the presence of $\mathrm{Na}^{+}$was apparently higher than others, which was the same as the result during the process of adsorption. Simultaneity, the final $\mathrm{NO}_{2}{ }^{-}$and $\mathrm{NH}_{4}{ }^{+}$concentrations were obviously different for various nitrate salts. The final $\mathrm{NO}_{2}{ }^{-}$concentration decreased with the increase of nitrate catalytic reduction removal efficiency, which meant favorable effect on nitrate catalytic reduction advanced nitrite reduction alike. Additionally, the $\mathrm{NH}_{4}{ }^{+}$accumulation was the lowest in the presence of $\mathrm{Na}^{+}$.

It has been widely known that the nitrate reduction efficiency and the selectivity to $\mathrm{N}_{2}$ are severely limited by diffusion [22]. During the process of nitrate catalytic reduction, $\mathrm{OH}^{-}$ions were produced continuously and baffled the access of nitrate and nitrite to the surface of the catalyst. With this respect, one can conclude that faster removal of $\mathrm{OH}^{-}$ions from the surface of catalyst would lead to faster regeneration of active sites. In other words, a large number of Pd-Cu sites can be accessed by nitrate and nitrite in the subsequent reaction cycles. Accordingly, different effect of cations on nitrate and nitrite hydrogenation might be ascribed to various affinities toward $\mathrm{OH}^{-}$, which was related with physical properties of cations, such as valence, crystal ionic radius and solubility constant of hydroxide. With the increase of valence and the decrease of ionic radius, attraction forces towards $\mathrm{OH}^{-}$improved. Thus, $\mathrm{OH}^{-}$on the surface of the catalyst can be quickly withdrawed. Moreover, the lower the solubility constant of hydroxide precipitation was, the easier the combination of $\mathrm{OH}^{-}$ions with cations to form the precipitation was. For the cations employed in this experiment, the solubility constant of hydroxide precipitation according to the order: $\quad \mathrm{Fe}(\mathrm{OH})_{3}<\mathrm{Mn}(\mathrm{OH})_{2}<\mathrm{Mg}(\mathrm{OH})_{2}<\mathrm{Ca}(\mathrm{OH})_{2}<\mathrm{NaOH}$ $\left(\mathrm{Fe}(\mathrm{OH})_{3}: \quad K_{\mathrm{sp}}=4 \times 10^{-38} ; \quad \mathrm{Mn}(\mathrm{OH})_{2}: \quad K_{\mathrm{sp}}=1.9 \times 10^{-13}\right.$; $\mathrm{Mg}(\mathrm{OH})_{2}: K_{\text {sp }}=1.8 \times 10^{-11} ; \mathrm{Ca}(\mathrm{OH})_{2}: K_{\mathrm{sp}}=5.5 \times 10^{-6}$ at $298 \mathrm{~K}$ ), which was just contrary to the order of the nitrate and nitrite removal efficiency. That is, more hydroxide precipitation made more $\mathrm{OH}^{-}$in the solution reduced, and thus improved nitrate removal efficiency and decreased the nitrite accumulation. Additionally, the lower final $\mathrm{pH}$ in the presence of bivalent and trivalent cations also demonstrated that more $\mathrm{OH}^{-}$ions in the solution were removed.

\subsubsection{The effect of co-anions in water}

$\mathrm{Cl}^{-}, \mathrm{SO}_{4}{ }^{2-}$ and $\mathrm{HCO}_{3}{ }^{-}$are common co-existing anions together with $\mathrm{NO}_{3}{ }^{-}$in water. The effect of these anions in water on the adsorption and catalytic reduction of nitrate by $\mathrm{HT} 3(\mathrm{Pd} / \mathrm{Cu})$ was studied in Fig. 5. Obviously, the presence of $\mathrm{Cl}^{-}, \mathrm{SO}_{4}{ }^{2-}$ and $\mathrm{HCO}_{3}{ }^{-}$anions suppressed the adsorption and reduction of $\mathrm{NO}_{3}{ }^{-}$. The inhibitory effect was in the order of $\mathrm{HCO}_{3}{ }^{-}>\mathrm{SO}_{4}{ }^{2-}>\mathrm{Cl}^{-}$. It was observed that there was only a little decrease on the adsorption and reduction of $\mathrm{NO}_{3}{ }^{-}$at the concentration range of $0-0.01 \mathrm{~mol} / \mathrm{L} \mathrm{Cl}^{-}$ions. When the concentration of $\mathrm{Cl}^{-}$ions was higher than $0.01 \mathrm{~mol} / \mathrm{L}$, the inhibitory effect increased apparently. Generally, the concentration of $\mathrm{Cl}^{-}$ions in the groundwater or surface water was lower than $0.01 \mathrm{~mol} / \mathrm{L}$. So $\mathrm{Cl}^{-}$ions in natural water exhibited little effect on nitrate adsorption and reduction over $\mathrm{HT} 3(\mathrm{Pd} / \mathrm{Cu})$ catalyst. However, the effect of $\mathrm{HCO}_{3}{ }^{-}$and $\mathrm{SO}_{4}{ }^{2-}$ on the removal of $\mathrm{NO}_{3}{ }^{-}$by adsorption and reduction was significant at the concentration range of $0-0.1 \mathrm{~mol} / \mathrm{L}$. With the increasing concentration of $\mathrm{HCO}_{3}{ }^{-}$and $\mathrm{SO}_{4}{ }^{2-}$, the amounts of $\mathrm{NO}_{3}{ }^{-}$removal by adsorption and reduction decreased quickly. For example, in the presence of $\mathrm{HCO}_{3}{ }^{-}$or $\mathrm{SO}_{4}{ }^{2-}$ at $0.001 \mathrm{~mol} / \mathrm{L}$, the nitrate removal by $\mathrm{HT} 3(\mathrm{Pd} / \mathrm{Cu})$ during the catalytic hydrogenation process dropped from 97 to about $86 \%$; at a concentration of $0.05 \mathrm{~mol} / \mathrm{L} \mathrm{HCO}_{3}{ }^{-}$or $\mathrm{SO}_{4}{ }^{2-}$, the nitrate removal declined to about $70 \%$; while at a concentration of $0.01 \mathrm{~mol} / \mathrm{L}$, the removal of nitrate decreased to $46 \%$. Additionally, during the catalytic hydrogenation process, the presence of $\mathrm{Cl}^{-}, \mathrm{SO}_{4}{ }^{2-}$ or $\mathrm{HCO}_{3}{ }^{-}$ increased the nitrite and ammonia accumulation. That is, $\mathrm{Cl}^{-}$, $\mathrm{SO}_{4}{ }^{2-}$ or $\mathrm{HCO}_{3}{ }^{-}$as co-existed anions inhibited the reduction of nitrite and decreased the selectivity to $\mathrm{N}_{2}$. The inhibitory order of $\mathrm{HCO}_{3}{ }^{-}>\mathrm{SO}_{4}{ }^{2-}>\mathrm{Cl}^{-}$was similar to that for nitrate adsorption and reduction. It was found that the inhibitive effect of $\mathrm{HCO}_{3}{ }^{-}$ions on the adsorption and reduction of nitrate was higher than that of $\mathrm{SO}_{4}{ }^{2-}$ and $\mathrm{Cl}^{-}$, which might be due to the identical structures of $\mathrm{NO}_{3}{ }^{-}$and $\mathrm{HCO}_{3}{ }^{-}$ions. They are both planar, and the angles between the $\mathrm{N}-\mathrm{O}$ and $\mathrm{C}-\mathrm{O}$ bonds are equal to $120^{\circ}$.

To clarify the inhibitory effect of $\mathrm{Cl}^{-}, \mathrm{SO}_{4}{ }^{2-}$ or $\mathrm{HCO}_{3}{ }^{-}$ on nitrate adsorption and reduction, we took the influence of $\mathrm{SO}_{4}{ }^{2-}$ ions, for example. During nitrate reduction process, infrared spectra of the catalyst at different reaction time was 

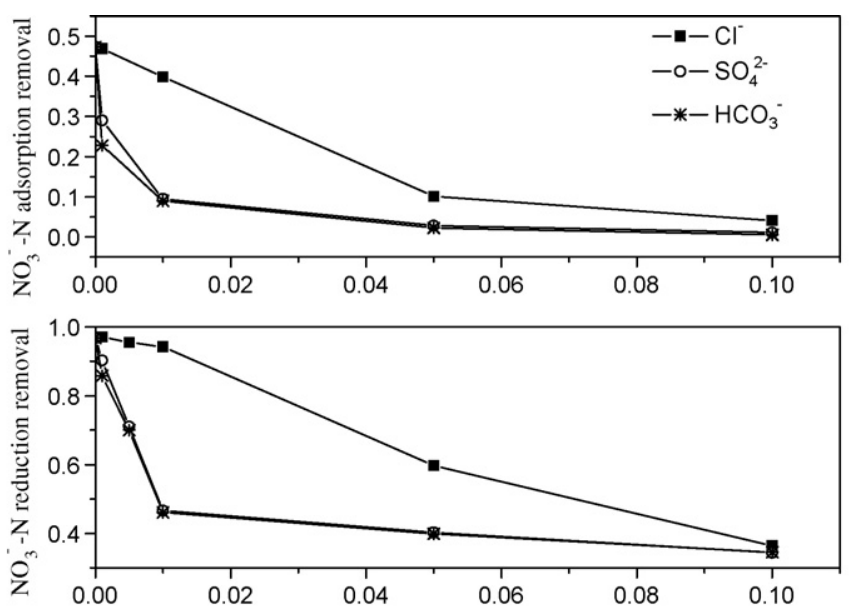

(a)
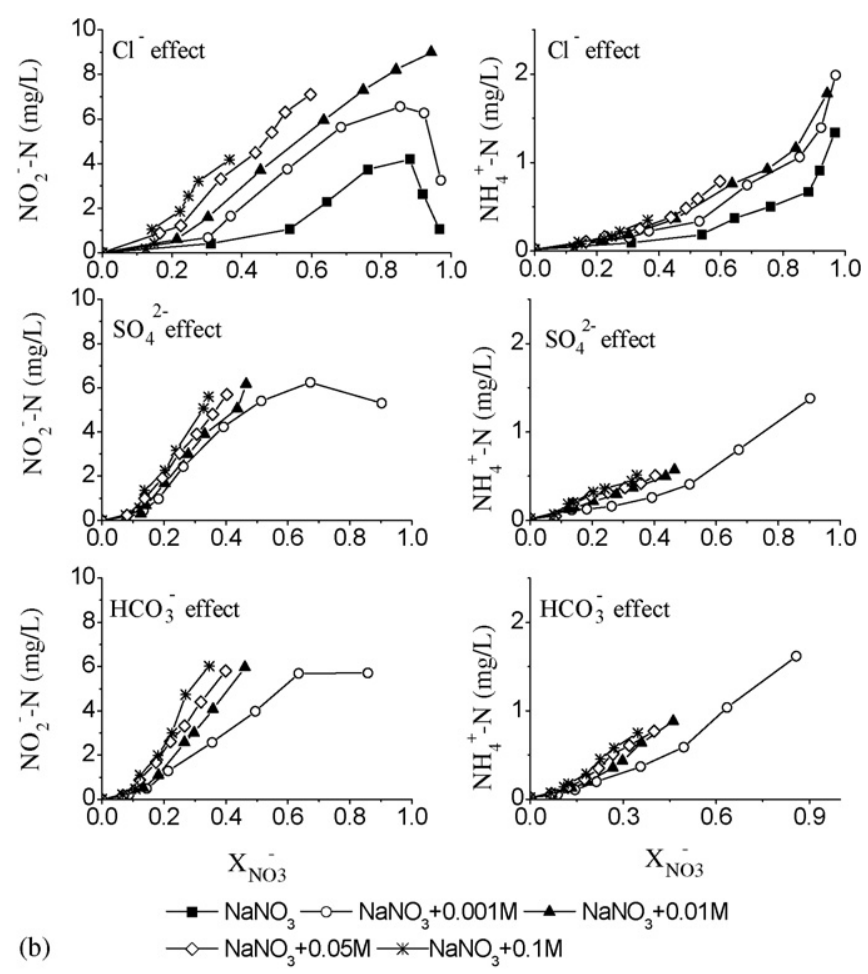

Fig. 5. The effect of the co-anions $\left(\mathrm{Cl}^{-}, \mathrm{SO}_{4}{ }^{2-}\right.$ and $\left.\mathrm{HCO}_{3}{ }^{-}\right)$on the adsorption and reduction of nitrate over $\mathrm{HT} 3(\mathrm{Pd}-\mathrm{Cu}), T=25^{\circ} \mathrm{C}$, without $\mathrm{pH}$ control: (a) nitrate removal efficiency with different co-anions concentration during adsorption and reduction process; (b) $\mathrm{NO}_{2}{ }^{-}$and $\mathrm{NH}_{4}{ }^{+}$concentration with $\mathrm{NO}_{3}{ }^{-}$ conversion at different co-anions concentration during nitrate reduction process $\left(X_{\mathrm{NO}_{3}{ }^{-}}=\left(\left[\mathrm{NO}_{3}{ }^{-}\right]_{t=0}-\left(\left[\mathrm{NO}_{3}{ }^{-}\right]_{t}\right) /\left(\left[\mathrm{NO}_{3}{ }^{-}\right]_{t=0}\right)\right.\right.$.

studied in Fig. 6. We can see that, when $\mathrm{SO}_{4}{ }^{2-}$ ions occurred in nitrate solution or not, it presented two infrared bands at 1647 and $1385 \mathrm{~cm}^{-1}$ assigned to the bending $\mathrm{O}-\mathrm{H}$ vibration of the water molecules and to the asymmetric stretching $\mathrm{N}-\mathrm{O}$ vibration of the nitrate ions, respectively. However, in nitrate solution with $\mathrm{SO}_{4}{ }^{2-}$ ions, the existence of an apparent infrared band at $1109 \mathrm{~cm}^{-1}$ can be found, but not be observed in the solution without $\mathrm{SO}_{4}{ }^{2-}$ ions. Therefore, it was concluded that the band at $1109 \mathrm{~cm}^{-1}$ was assigned to $\mathrm{SO}_{4}{ }^{2-}$. Moreover, during the course of the reaction, this band $\left(1109 \mathrm{~cm}^{-1}\right)$ increased grad-

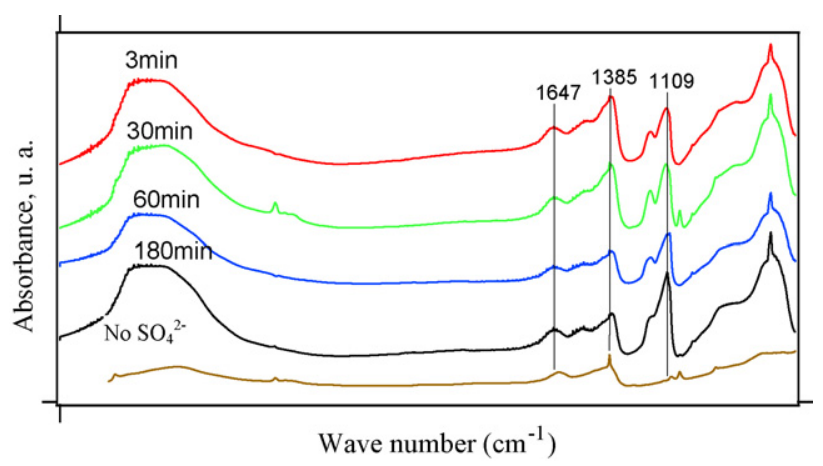

Fig. 6. Infrared spectra of $\mathrm{HT} 3(\mathrm{Pd}-\mathrm{Cu})$ catalyst withdrawn at different reaction times, $T=25^{\circ} \mathrm{C}$, without $\mathrm{pH}$ control, the concentration of $\mathrm{SO}_{4}{ }^{2-}$ is $0.01 \mathrm{~mol} / \mathrm{L}$.

ually. Therefore, by IR study, the effect of $\mathrm{SO}_{4}{ }^{2-}$ on nitrate reduction over $\mathrm{HT} 3(\mathrm{Pd} / \mathrm{Cu})$ catalyst could be attributed to competitive adsorption with nitrate on the catalyst surface, which leads to the active sites decreased apparently, and consequently nitrate adsorption and reduction decreased and nitrite was accumulated.

\subsection{The stability and reusability of $\mathrm{HT} 3(\mathrm{Pd}-\mathrm{Cu})$}

From a practical viewpoint, to evaluate the stability and reusability of $\mathrm{HT} 3(\mathrm{Pd}-\mathrm{Cu})$ must be required. After the reduction of nitrate, the dissolution of metals in solution at different initial $\mathrm{pH}$ was analyzed by ICP-AES (Table 1). In the neutral (pH 7.4) and alkaline ( $\mathrm{pH}$ 10.74) solution, no palladium ions were detected in the solution. The concentrations of copper, magnesium and aluminium ions were lower than $0.0025,0.477$ and $0.58 \mathrm{mg} / \mathrm{L}$, which were all lower than the standard for drinking water in China. However, in acid ( $\mathrm{pH}$ 3.77) solution, the dissolution of metals increased apparently. The concentrations of palladium and copper reached as high as 5.8 and $1.24 \mathrm{mg} / \mathrm{L}$, which accounted for 29 and $24.8 \%$ of the amount loaded on the catalyst, respectively. The concentrations of magnesium and aluminium ions were higher than $200 \mathrm{mg} / \mathrm{L}$. These results demonstrated that HT3(Pd-Cu) catalyst dissolved in acid solution, but keep stable in neutral and alkaline solution. Generally, most waters were about neutral or alkalescent. Therefore, the reduction of nitrate on $\mathrm{HT} 3(\mathrm{Pd}-\mathrm{Cu})$ catalyst may be used in most case.

Fig. 7 showed average activity of HT3(Pd-Cu) for nitrate reduction during five cycles. The experiment was conducted as follows. After the reaction, the catalyst was taken out by the centrifugation, and then washed to remove excess ions on the surface of the catalyst. Whereafter, the recycled catalyst was

Table 1

The dissolution of HT3(Pd-Cu $)$ at different initial $\mathrm{pH}\left(\mathrm{C}_{0}\left(\mathrm{NO}_{3}{ }^{-}\right)=100 \mathrm{mg} / \mathrm{L}\right.$, $2 \mathrm{~g} / \mathrm{L}$ catalyst, at $25^{\circ} \mathrm{C}$ )

\begin{tabular}{rllcc}
\hline $\mathrm{pH}$ & $\mathrm{Pd}(\mathrm{mg} / \mathrm{L})$ & $\mathrm{Cu}(\mathrm{mg} / \mathrm{L})$ & $\mathrm{Mg}(\mathrm{mg} / \mathrm{L})$ & $\mathrm{Al}(\mathrm{mg} / \mathrm{L})$ \\
\hline 3.77 & 5.8 & 1.24 & $>200$ & $>200$ \\
7.40 & - & 0.0025 & 0.477 & 0.39 \\
10.74 & - & - & 0.0051 & 0.58
\end{tabular}

-: lower than detective level by ICP-AES. 


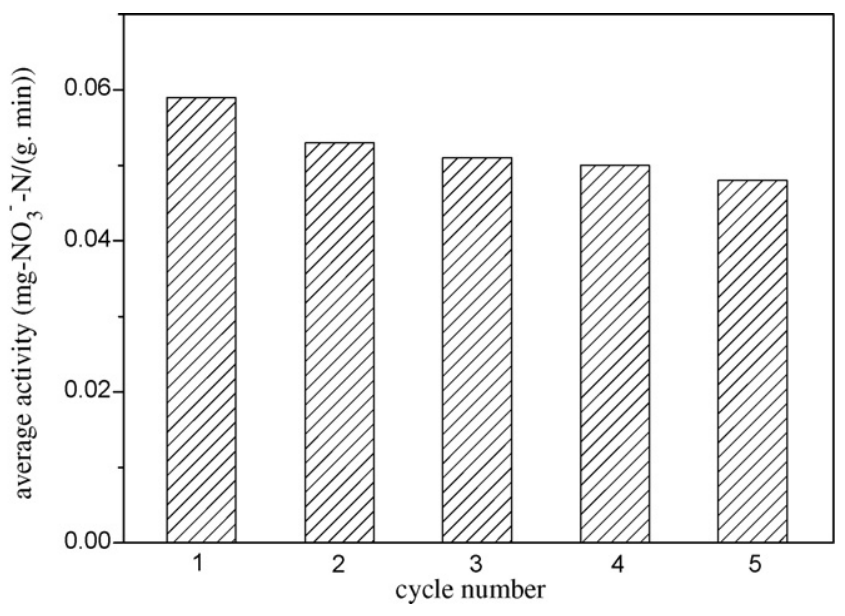

Fig. 7. Reusability of $\mathrm{HT} 3(\mathrm{Pd}-\mathrm{Cu})$ for nitrate reduction for an initial $\mathrm{NO}_{3}{ }^{-}$ concentration of $100 \mathrm{mg} / \mathrm{L}, 2 \mathrm{~g} / \mathrm{L}$ catalyst, at $25^{\circ} \mathrm{C}$, without $\mathrm{pH}$ control.

dried at $60{ }^{\circ} \mathrm{C}$ and weighed. Finally, the capacity of the recycled catalyst for nitrate reduction was examined again. It was observed that the average activity decreased obviously in the first cycle and then decreased slowly with the increase of cycles, which indicated that HT3(Pd-Cu) catalyst exhibited excellent stability and may be used for a long term.

\subsection{Conclusions}

In this paper, the effect of liquid property on adsorption and catalytic reduction of nitrate over hydrotalcite-supported $\mathrm{Pd}-\mathrm{Cu}$ catalyst were investigated systematically. The results demonstrated that temperature, $\mathrm{pH}$ and co-existed ions in water showed apparent influence on nitrate removal. At different reaction temperature $\left(10,25\right.$ and $\left.35^{\circ} \mathrm{C}\right), \mathrm{HT} 3(\mathrm{Pd} / \mathrm{Cu})$ catalyst possessed apparent adsorption capacity for $\mathrm{NO}_{3}{ }^{-}$, which could be explained by considering the capacity of hydrotalcite to concentrate anions in the interlayer space. Adsorption isotherms for $\mathrm{NO}_{3}{ }^{-}$were good agreement with Langmuir's equation. Moreover, Higher reaction temperature advanced nitrate adsorption and reduction, and simultaneously decreased the accumulation of $\mathrm{NO}_{2}{ }^{-}$and $\mathrm{NH}_{4}{ }^{+}$. When the initial $\mathrm{pH}$ of solution was from 5.25 to 7.4 , the initial $\mathrm{pH}$ exhibited little influence on the nitrate adsorption and catalytic reduction, which was due to high $\mathrm{pH}$ buffering capacities of HT3(Pd-Cu) catalyst. However, at too low initial $\mathrm{pH}$ of 3.77 , the dissolution of $\mathrm{HT} 3(\mathrm{Pd} / \mathrm{Cu})$ resulted in a significant decline in nitrate adsorption removal. At too high initial $\mathrm{pH}$ of 10.74 , buffering effect of $\mathrm{HT} 3(\mathrm{Pd} / \mathrm{Cu})$ disappeared. High concentration of $\mathrm{OH}^{-}$ions decreased nitrate adsorption and reduction. Co-existed cations in water with higher valence and lower crystal ionic radius and solubility constant of hydroxide showed stronger affinity toward $\mathrm{OH}^{-}$and consequently increased the concentration of active sites accessible to $\mathrm{NO}_{3}{ }^{-}$ and $\mathrm{NO}_{2}{ }^{-}$. Thus, when using various nitrate salts as a source of nitrate ions, nitrate adsorption and reduction removal efficiency decreased in the order: $\mathrm{Fe}^{3+}>\mathrm{Mn}^{2+}>\mathrm{Mg}^{2+}>\mathrm{Ca}^{2+}>\mathrm{Na}^{+}$. The presence of $\mathrm{Cl}^{-}, \mathrm{SO}_{4}{ }^{2-}$ and $\mathrm{HCO}_{3}{ }^{-}$anions suppressed the adsorption and reduction of $\mathrm{NO}_{3}{ }^{-}$on $\mathrm{HT} 3(\mathrm{Pd}-\mathrm{Cu})$, which could be attributed to competitive adsorption with nitrate on the catalyst surface. Additionally, few metals dissolved in neutral and alkaline solution. The activity of HT3(Pd-Cu) for nitrate reduction kept steady after repeated use, which favored the long-term use.

\section{Acknowledgements}

This work was supported by the Funds for Creative Research Groups of China (Grant No. 50621804) and National High Technology Research and Development Program of China (Grant No. 2006AA06Z302).

\section{References}

[1] A. Pintar, Catal. Today 77 (2003) 451-465.

[2] M. Super, H.V. Heese, D. MacKenzie, W.S. Dempster, J. Plessis, J.J. Ferreira, Water Res. 15 (1981) 1265-1270.

[3] A. Santafé-Moros, J.M. Gozálvez-Zafrilla, J. Lora-García, Desalination 185 (2005) 281-287.

[4] J. Wiśniewski, A. Różańska, Desalination 191 (2006) 210-218.

[5] H.S. Moon, S.W. Chang, K. Nam, J. Choe, J.Y. Kim, Environ. Pollut. 144 (2006) 802-807.

[6] V. Laurin, N. Labbé, P. Juteau, S. Parent, R. Villemur, Water Res. 40 (2006) 1836-1840.

[7] K.D. Vorlop, T. Tacke, Chem. Ing. Tech. 61 (1989) 836-845.

[8] U.M. Meytal, M. Sheintuch, Catal. Today 102 (2005) 121-127.

[9] A.E. Palomares, J.G. Prato, F. Marquez, A. Corma, Appl. Catal. B: Environ. 41 (2003) 3-13.

[10] A. Garron, K. Lázár, F. Epron, Appl. Catal. B: Environ. 65 (2006) 240-248.

[11] A. Garron, K. Lázár, F. Epron, Appl. Catal. B: Environ. 59 (2005) 57-69.

[12] G. Centi, S. Perathoner, Appl. Catal. B: Environ. 41 (2003) 15-29.

[13] L. Lemaignen, C. Tong, V. Begon, R. Burch, D. Chadwick, Catal. Today 75 (2002) 43-48.

[14] A. Pintar, J. Batista, J. Levec, Chem. Eng. Sci. 56 (2000) 1551-1559.

[15] Y. Wang, J.H. Qu, H.J. Liu, The Second Japan-China Workshop on Environmental Catalysis and Eco-materials, Fukuoka, Japan, 2005.

[16] T.M. Jyothi, T. Raja, B.S. Rao, Mol. Catal. A: Chem. 168 (2001) 187-191.

[17] F. Basile, G. Fornasari, M. Gazza, Appl. Clay Sci. 16 (2000) 185-200.

[18] S. Yata, Clays Clay Miner. 31 (1983) 305-311.

[19] F. Cavani, F. Trifiro, A. Vaccari, Catal. Today 11 (1991) 173-301.

[20] D. Tichit, M.H. Lhouty, A. Guida, B.H. Chiche, F. Figueras, A. Auroux, D. Bartalini, E. Garrone, J. Catal. 151 (1995) 50-59.

[21] Y. You, G.F. Vance, H. Zhao, Appl. Clay Sci. 20 (2001) 13-25.

[22] U. Prusse, K.D. Vorlop, J. Mol. Catal. A: Chem. 173 (2001) 313-328. 